\title{
The influence of light regime on the growth data and pigment composition of the plant Gentiana lutea cultured in vitro
}

\author{
L. R. Hrytsak*, A. I. Herts*, N. V. Nuzhyna**, M. M. Cryk*, V. V. Shevchenko***, N. M. Drobyk* \\ *Ternopil Volodymyr Hnatiuk National Pedagogical University, Ternopil, Ukraine \\ **Taras Shevchenko National University of Kyiv, Kyiv, Ukraine \\ ***Institute of Plant Physiology and Genetics, National Academy of Sciences of Ukraine, Kyiv, Ukraine
}

\section{Article info}

Received 10.03.2018

Received in revised form 12.04.2018

Accepted 15.04.2018

Ternopil Volodymyr Hnatiuk National Pedagogical University,

M. Kryvonosa st., 2

Ternopil, 46027, Ukraine.

Tel.: +38-067-453-94-19.

E-mail: hrytsak1972@gmail.com

Kyiv Taras Shevchenko National University, Symona Petlyury st.

1, Kyiv, 01032, Ukraine.

Tel.: +38-067-339-97-73.

E-mail:nuzhynan@gmail.com

Institute of Plant Physiology and Genetics, National Academy of Sciences of Ukraine, Vasylkivska st., 31/17,

Kyiv, 03022, Ukraine.

Tel.: +38-067-405-79-2

E-mail: biochemkiev@ukr.net
Hrytsak, L. R., Herts, A. I., Nuzhyna, N. V., Cryk, M. M., Shevchenko, V. V., \& Drobyk, N. M. (2018). The influence of light regime on the growth data and pigment composition of the plant Gentiana lutea cultured in vitro. Regulatory Mechanisms in Biosystems, 9(2), 258-266. doi:10.15421/021838

New technologies of reintroduction of plant species presuppose implementing both traditional and biotechnological methods for obtaining certain planting materials. However, plants cultivated in vitro exist in specific conditions that lead to changes in their structural and functional state. This explains why it is hard for them to adapt to ex vitro and in situ conditions. Therefore, there is a need for the development of a multistage method of cultivating in vitro plants that would make the influence on their adaptive mechanism in ex vitro and in situ conditions possible. One of its stages is the optimization of the light regime of cultivation which can both initiate the change of the state of the photosynthetic apparatus of plants and increase their bioproductivity stimulating the work of their protective system. This work studies changes in the morphogenesis, growth data and pigment composition of the rare species of Gentiana lutea L. of three populations in the Ukrainian Carpathian (mountains Pozhyzhevska and Sheshul-Pavlyk, plateau Lemska) in vitro focusing particularly on the cultivation light regime. The research has proved the inefficiency of using fluorescent lamps of daylight lamps (LD) type as source of illumination because the low intensity of luminous flux in the area of photosynthetically active radiation (PAR), as well as high proportion of wavelength of blue (400-500 nm) and green (500-600 nm) range in the spectrum cause specific reactions of photomorphogenesis, which, despite the high content of pigments in plastids, lead to poor development of root systems, stretching the stems, formation of small leaves with thin leaflet plate, generally low productivity and low adaptive potential of $G$. lutea plants to ex vitro and in situ conditions. Complement of cold white light lamps to the fluorescent lamps LD type in the ratio of $1: 1$ enables one to increase the intensity of illumination in the field of PAR and raise the fraction of wavelength of red range $(600-700 \mathrm{~nm})$. Such light conditions both improve the bio-productivity of G. lutea plants of all three populations cultured in vitro in comparison to the LD type regimen, reducing the content of chlorophyll $b$ and carotenoids in light-harvesting complexes of photosystems and facilitate an increase in the microclonal multiplication factor without using higher concentrations of exogenous growth regulators, which significantly reduces the cost of the process of obtaining planting materials. It was proved that a combination of LD type lamps, cold white light lamps and phytolamps in the ratio $1: 1: 0.6$ should be used on the final stages of preparation of the planting material of G. lutea before transferring it to ex vitro and in situ conditions. This relates to the fact that the increase of the wavelength of the red range results in the widening of the active surface of the leaves, rise in the content of photosynthetic pigments, and the noticeable growth of the aboveground and underground parts of the plants. The article assumes that the use of such illumination mode will ensure a faster transition of cultured in vitro G. lutea plants from heterotrophic to autotrophic nutrition, improving their adaptive potential and enabling easier adaptation to non-sterile ex vitro and in situ conditions.

\section{Вплив світлового режиму на ростові параметри та пігментний склад культивованих in vitro рослин Gentiana lutea}

\author{
Л. Р. Грицак*, А. І. Герц*, Н. В. Нужина**, М. М. Крук*, В. В. Шевченко***, Н. М. Дробик* \\ *Тернопільський наџіональний педагогічний університет імені Володимира Гнатюка, Тернопіль, Україна \\ **Київський національний університет імені Тараса Шевченка, Київ, Україна \\ ***Інститут фізіології рослин і генетики НАН України, Київ, Україна
}

Нові технології реінтродукції видів рослин передбачають застосування не лише традиційних, а і біотехнологічних методів для отримання посадкового матеріалу. Однак культивовані in vitro рослини перебувають у специфічних умовах, які викликають зміни їх структурно- 
функціонального стану. Це пояснює складність адаптації до умов ех vitro та in situ. Тому виникає необхідність розроблення багатоступеневої технології культивування in vitro рослин, яка б дозволила цілеспрямовано впливати на їх адаптаційний потенціал до умов ех vitro та in situ. Один з їі етапів - оптимізація світлового режиму культивування, здатного не лише ініціювати зміну стану фотосинтетичного апарату рослин, а й підвищувати їх біопродуктивність та стимулювати роботу захисної системи. Вивчено зміну морфогенезу, ростових параметрів та пігментного складу рослин in vitro трьох популяцій Українських Карпат (із гір Пожижевська, Шешул-Павлик і полонини Лемська) рідкісного виду Gentiana lutea L. залежно від світлового режиму культивування. Встановлено недоцільність використання як джерела освітлення люмінесцентних ламп денного світла, оскільки низька інтенсивність їх світлового потоку в області фотосинтетично активної радіації, висока частка у спектрі хвиль синього (400-500 нм) та зеленого (500-600 нм) діапазонів запускають специфічні реакції фотоморфогенезу, які, незважаючи на високій вміст пігментів у пластидах, спричиняють слабкий розвиток кореневої системи, витягування стебел, утворення дрібних листків із тонкою листковою пластинкою, загальної низької продуктивності та низького адаптаційного потенціалу рослин G. lutea до умов ех vitro та in situ. Корекція світлового режиму ламп денного світла лампами холодного білого світла у співвідношенні 1 : 1 дозволяє підвищити інтенсивність освітлення в області ФАР та збільшити частку хвиль червоного діапазону (600-700 нм). Такі світлові умови не лише поліпшують біопродуктивність культивованих in vitro рослин G. lutea усіх трьох популяцій порівняно з режимом ЛД ламп, зменшують вміст хлорофілу $b$ і каротиноїдів у світлозбиральних комплексах фотосистем, а і дозволяють збільшити коефіцієнт мікроклонального розмноження без додаткового застосування концентрацій екзогенних регуляторів росту. Це значно здешевлює процес отримання посадкового матеріалу. Комбінацію люмінесцентних ламп денного світла, холодного білого світла та фітоламп у співвідношенні $0,6: 1: 1$ доцільно використовувати на заключних етапах підготовки посадкового матеріалу G. lutea до перенесення в умови ex vitro та in situ. Це пов'язано з тим, що підвищення частки хвиль червоного діапазону сприяє збільшенню ефективної поверхні листків, вмісту фотосинтетичних пігментів, найбільшому приросту надземної та підземної частин рослин. Зроблено припущення, що використання такого режиму освітлення забезпечить швидший перехід культивованих in vitro рослин G. lutea від гетеротрофного до автотрофного живлення, поліпшить їх адаптаційний потенціал і дозволить легше пристосуватися до нестерильних умов ех vitro та in situ.

Ключові слова: культивування in vitro; морфогенез; інтенсивність світлового потоку; фотосинтетично активна радіація; спектри випромінювання

\section{Ветуп}

Антропогенна трансформація довкілля викликала руйнування структури більшості рослинних угрупувань. Це спричинило порушення популяцій багатьох видів, заміну конкурентного типу стратегій на стрестолерантний або рудеральний з ознаками дигресії, зниження показників продуктивності та життєвості рослин i, як наслідок, фрагментацію місць зростання, зменшення кількості особин у популяціях і генетичну ерозію (Kramer \& Наvens, 2009; Mayorova et al., 2015a). 3 цієї причини в останні десятиліття інтенсивно розробляються нові інтегровані технології, які поєднують у собі елементи збереження як in situ, так і ex situ та передбачають реінтродукцію рідкісних та зникаючих видів у природні умови, де вони раніше росли, однак були знищені внаслідок антропогенного навантаження на популяції (Burney \& Burney, 2007; Maschinski \& Albrecht, 2017). Volis \& Blecher (2010) запропонували нову стратегію реінтродукції, під назвою «квазі in situ», яка передбачає п'ять важливих етапів від первинного аналізу розподілу рідкісних видів у природі, відбору їх матеріалу, розмноження рослин в умовах, які максимально відповідають їх екологічним потребам, дослідження життєвого циклу видів та визначення комплексу абіотичних та біотичних факторів, що впливають на їх популяційну структуру, до заключного етапу моніторингу успішності реінтродукції цих таксонів у природні умови. При цьому поряд із традиційними методами розмноження та отримання посадкового матеріалу все частіше пропонується використовувати біотехнологічні (Sarasan et al., 2006; Bisht et al., 2017; Keziah \& Devi, 2017), зокрема, метод мікроклонального розмноження in vitro, який дозволяє швидко отримати рослинний матеріал, необхідний для відтворення та повернення у природу представників багатьох видів рослин (Kiran et al., 2014), у тому числі видів роду Gentiana L. (Drobyk et al., 2015), зокрема, його рідкісного високогірного таксона Gentiana lutea L. (Drobyk et al., 2015; Hrytsak et al., 2017).

Рослини, отримані 3 використанням культури клітин і тканин in vitro, здатні швидше проходити етапи онтогенезу, характеризуються високою якістю, високим коефіцієнтом розмноження, інтенсивним приростом біомаси тощо (Belokurova, 2010; Oceania et al., 2015). Однак процеси росту, розвитку та продуктивність культивованих in vitro рослин залежать від багатьох факторів, у тому числі від стану їх фотосинтетичного апарату. На думку V. P. Kucheriavyi et al. (2003), це пояснюється тим, що функціональні процеси в рослинному організмі за значимістю розташовуються у такій послідовності: фотосинтез, дихання, біосинтез вторинних речовин, транспірація, ріст і розвиток. Функціонування фотосинтетичної системи, з одного боку, залежить від ендогенної регуляції (гормональної та метаболічної) (Ling \& Jarvis,
2015; Sun \& Zerges, 2015), а з іншого, від екзогенної, оскільки пігмент-білковий комплекс фотосинтетичних мембран реагує на зміну зовнішніх умов вирощування (Gururani et al., 2015).

Культивування рослин in vitro передбачає створення штучного живильного середовища, що за багатьма параметрами відрізняється від природних умов зростання видів (Cruz-Cruz et al., 2013). Відмінності стосуються також інтенсивності та якості освітлення, газового складу повітря культиваційного посуду, рівня відносної вологості, особливостей мінерального живлення тощо. Живильні середовища часто збагачені сахарозою, яка, з одного боку, є джерелом карбону та зумовлює швидший ріст рослин, а, 3 іншого, пригнічує накопичення хлорофілів, зменшує активність ферментів хлоропластів і процеси фіксації $\mathrm{CO}_{2}$ (Banas \& Gabrys, 2007; Dingenen et al., 2016). Зміна складу та метаболізму пігмент-білкових комплексів фотосинтетичних мембран хлоропластів впливає на загальний рівень метаболізму, рух асимілятів, синтез ростових речовин тощо (Schöttler \& Tóth, 2014; Ling \& Jarvis, 2015). Тому це позначається не лише на формуванні фотосинтетичної системи, а й на її здатності у подальшому адаптуватися до функціонування в умовах ex vitro (Kodun-Ivanova, 2017).

Із літературних джерел відомо, що видова специфіка рослин визначає їх потреби у спектрі світла та його інтенсивності випромінювання у різних ділянках фотосинтетично активної радіації (ФАР) (Ouzounis et al., 2015). Для промислової технології вирощування рослин використовують різне співвідношення хвиль синього (Ес), зеленого (Ез) та червоного (Еч) діапазонів, зокрема: для сціофітів а для геліофітів -

$$
\text { Ес : Ез : Еч }=15-20 \%: 35-45 \%: 40-45 \% \text {, }
$$

$$
\text { Ес : Ез : Еч }=10-20 \%: 15-20 \%: 60-75 \% \text {. }
$$

При цьому мінімально допустимий діапазон інтенсивності ФАР, за якого вегетативні органи ще здатні рости, становить 15$30 \mathrm{BT} / \mathrm{m}^{2}$; оптимальна для сціофітів інтенсивність світлового потоку $70 \mathrm{BT} / \mathrm{m}^{2}$, а для геліофітів її діапазон коливається в межах 150-220 BT/M² (Govorov et al., 2011).

Рідкісний вид G. lutea - високогірний таксон, природні популяції якого зростають у «холодній зоні» субальпійського поясу Українських Карпат (Kobiv et al., 2017), Піренеїв та Малої Азії (Rossi et al., 2015). В Українських Карпатах протягом вегетаційного періоду кількість днів із середньодобовою температурою $+15^{\circ} \mathrm{C}$ не перевищує $60-70$, внесок прямої радіації в сумарну менший 40\% (1234 МДж/м²) і навіть влітку через значну хмарність не досягає середнього рівня, характерного для інших територій (Rybchenko \& Savchuk, 2015). За таких умов освітлення у спектрі випромінювання збільшується частка синьо-фіолетових хвиль. Це зумовлює розвиток компенсаторних механізмів у високогірних рослин, які змінюють інтенсивність фотосинтетич- 
них реакцій, співвідношення світлозбиральних пігментів у реакційних центрах фотосистеми II, перебігу фізіологічних та біохімічних процесів (Kuster et al., 2016; Gong et al., 2018). Тому вибрати оптимальний для культивування в умовах in vitro високогірних рослин режим освітлення, який би не порушував процеси їх морфогенезу, дуже складно.

Поетапне зменшення у живильному середовищі МС/2 (середовище MC (Murashige \& Skoog, 1962) з половинним вмістом макро- та мікросолей) концентрації $\mathrm{NH}_{4} \mathrm{NO}_{3}$, заміна джерела карбону із сахарози на низькомолекулярний маніт, використання як підтримувального субстрату агару у поєднанні 3 перлітом сприяє ефективнішому вкоріненню мікроклонально розмножених рослин G. lutea, поліпшує їх адаптацію до умов ex vitro та забезпечує високий (до 51\%) відсоток їх приживання у природі на першому році життя (Mayorova et al., 2015b). Отримані в таких умовах біотехнологічні рослини мали морфологічні ознаки, які зазвичай спостерігають за недостатнього освітлення, або за неоптимального спектрального складу світла, що, можливо, стало причиною значного зменшення показників виживання особин (до 15\%) упродовж наступних двох років. Тому для успішної реінтродукції $G$. lutea необхідне обгрунтування та розроблення ефективнішої, багатоступінчастої технології адаптації отриманих in vitro рослин цього таксона як до умов ex vitro, так і до in situ. Ця технологія повинна сприяти швидкій структурній перебудові культивованих in vitro рослин $G$. lutea під час перенесення їх в умови ex vitro та in situ; не допускати порушення функціонування механізмів їх фотозахисту за суттєвого збільшення кількості прямої та сумарної сонячної радіації (до $350-400$ Вт/м²) в умовах відкритого грунту (Sáez, 2012). Оскільки Viazov \& Shalyho (2016) на прикладі Cucumis sativus L. показали, що оптимізація світлового режиму не лише здатна викликати модифікацію стану фотосинтезувального апарату рослин, а і стимулювати роботу їх захисної системи, у тому числі антиоксидантної та антипатогенної, одним i3 підходів для вирішення вищезгаданої проблеми може стати зміна світлового режиму під час вирощування рослин in vitro.

Виходячи 3 вищезазначеного, мета наших досліджень - оцінити залежність ростових параметрів, культивованих in vitro pocлин G. lutea, вмісту та співвідношення в них основних фотосинтезувальних пігментів (хлорофілів $a, b$, каротиноїдів) від спектрального складу та інтенсивності світлового потоку в області ФАР штучних джерел освітлення.

Результати цих досліджень послужать основою для оптимізації світлового режиму вирощування in vitro рослин G. lutea та розроблення схеми підвищення їх адаптаційного потенціалу на першому етапі багатоступінчастої технології стабілізації / реінтродукції його популяцій в Українських Карпатах.

\section{Матеріал і методи досліджень}

Досліджували рідкісний лікарський вид - G. lutea, який росте у високогір'ї Українських Карпат у межах гіпсометричних рівнів 1300-1500 м н. р. м.

Вихідний насіннєвий матеріал зібрано під час експедицій в Українських Карпатах у популяціях на горах (г.) Пожижевська (хр. Чорногора, Надвірнянський р-н, Івано-Франківська обл., 1427 м н. р. м, 4809'19' N, 24³1’94’’ Е), г. Шешул-Павлик (хр. Чорногора, Рахівський р-н, Закарпатська обл., 1627 м н. р. м., 4808'99'’ N, 2421'58', E), полонині (п.) Лемська (хр. Чорногоpa, Рахівський р-н, Закарпатська обл., 1816 м н. р. м., 4805’34’’ N, 24³4’89’’ Е). Збирали насіння G. lutea відповідно до дозволу, наданого Міністерством екології і природних ресурсів України №4344/11-09 від 12.05.2009 р. та №7657/19-12 від 25.07.2012 р.

Отримані in vitro проростки пересаджували у рідке живильне середовище $\mathrm{MC} / 2$, доповнене $0,1-0,2$ мг/л кінетину. Мікроклональне розмноження рослин проводили за раніше розробленими методиками (Strashniuk et al., 2004), використовуючи для досліджень апікальні живці $з$ двома парами листків. Для їх росту та вкорінення використовували живильне середовище $\mathrm{MC} / 2$, доповнене 0,1 мг/л кінетину.
Мікроклонально розмножені рослини культивували у пробірках під люмінесцентними лампами денного світла (ЛД) фірми «General Electric» (Hungary) за інтенсивності світлового потоку в області ФАР 25 Вт/м², фотоперіод 16/8, температура 19-21 ${ }^{\circ} \mathrm{C}$. Ці умови культивування розглядали як контроль. Згідно $з$ технічними характеристиками, коефіцієнт корисної дії ЛД ламп в області ФАР коливається в межах 9-12\% (або 3,71-4,94 Вт/м²), спектральний склад: $22,3 \%-400-450 \mathrm{Hм}, 19,5 \%-450-500$ нм, $22,3 \%-500-550$ нм, 22,3\% - 550-600 нм, 11,8\% - 600-650 нм, 3,7\% - 650-700 нм (Velyt \& Guzyk, 2013).

Для експерименту відібрано по 10 вихідних, отриманих шляхом пророщування in vitro насінин рослин G. lutea з трьох популяцій (г. Пожижевська, г. Шешул-Павлик, п. Лемська), які мікроклонально розмножували $з$ метою отримання потрібної для дослідження кількості рослинного матеріалу. Для з'ясування впливу інтенсивності освітлення та спектрів випромінювання на ростові параметри та вміст пігментів у культивованих in vitro рослинах додатково використано люмінесцентні лампи Lumilux 36W 840 холодного білого світла (ЛХБ) та фітолампи Fluora L36W/77 G13 (ФЛ) фірми Osram (Німеччина). Світловий потік ЛХБ згідно з технічними даними - 2700 люмен, його інтенсивність в області ФАР (7,5 ВТ/м²), спектральний склад у діапазоні ФAP: $12,8 \%$ - 400-450 нм, 20,1\% - 450-500 нм, $12,3 \%$ - 500550 нм, 29,7\% - 550-600 нм, 20,2\% - 600-650 нм, 4,9\% - 650700 нм (Velyt \& Guzyk, 2013)). ФЛ мають такі характеристики: інтенсивність в області ФАР - 35,28 Вт/м² або 28,22 Вт/м ${ }^{2}$ через 5000 годин, спектральний склад: 15,5\% - 400-450 нм, 3,7\% 450-500 нм, 7,4\% - 500-550 нм, 9,6\% - 550-600 нм, 59,9\% 600-650 нм, 3,9\% - 650-700 нм (Velyt \& Guzyk, 2013). Застосування цих ламп дозволило підвищити інтенсивність світлового потоку з 25 до 135 Вт/м² і здійснити два варіанти корекції спектрального складу (СК) контролю:

- перший варіант: інтенсивність світлового потоку в області ФАР 44 Вт/м², співвідношення ламп ЛД до ЛХБ становить $1: 1$, сумарний спектральний склад:

Ес : Ез : Еч $=37,35 \%: 42,35 \%: 20,3 \%$;

- другий варіант: інтенсивність світлового потоку в області ФАР - 135 Вт/м², співвідношення ламп ЛД до ЛХБ та ФЛ становить $0,6: 1: 1$, спектральний склад:

Ес : Ез : Еч $=29,5 \%: 32,42 \%: 38,08 \%$.

У кожному із трьох варіантів (контроль та два варіанти корекції) використовували по 30 рослин - по 10 із кожної з трьох популяцій. Інтенсивність світлового потоку в області ФАР розраховували згідно з «Нормами технологічного проектування теплиць і тепличних комбінатів для вирощування овочів та розсади НТП10-95», за формулою:

$$
N=\frac{S W}{W_{\text {л }}}
$$

де $N$ - кількість ламп (шт.); $S$ - площа приміщення (м²); $W$ - питома потужність освітленості $\left(\mathrm{BT} / \mathrm{M}^{2}\right) ; W_{л}-$ питома потужність лампи в області ФАР (Вт) (Velyt \& Guzyk, 2013).

Ростові параметри аналізували через 90 діб культивування. Підраховували кількість листків (NL), визначали висоту стебла (LS), довжину міжвузлів (LIN), сиру масу листків (WL), кореня (WR), надземної частини (WS) та рослин у цілому (WP); площу усієї листкової поверхні (A) та площу одного листка (ALI) вимірювали за допомогою програми Petiole (https://petioleapp.com). Аналіз цих параметрів дозволив визначити ефективність утворення рослинами листкової поверхні та показники розвитку фотосинтетичного апарату (Bidl, 1989): відношення площі листків до біомаси рослин (LAR), фотосинтетичне зусилля (LWR), площу одиниці маси листка (SLA), а також відношення біомаси стебла до біомаси кореня (LSR).

Пігменти з листків екстрагували диметилсульфоксидом (ДМСО, $\left.\left(\mathrm{CH}_{3}\right)_{2} \mathrm{SO}_{2}\right)$ за методикою Mezhunts (2009). Визначення вмісту хлорофілів $a(\mathrm{Chl} a), b(\mathrm{Chl} b)$ та суми каротиноїдів (Carot) проводили на спектрофотометрі СФ-46 за довжини хвиль 663, 645 i 440,5 нм, відповідно. Концентрацію хлорофілів визначали за фор- 
мулами Макінні - Арнона, а суму каротиноїдів - Веттштейна (Mezhuts, 2009). Критерій достовірної різниці групових середніх Тьюкі (Honestly Significant Difference) розраховано за допомогою програмного забезпечення Prism 6 та R-studio. Для узагальнення даних та виявлення взаємозв'язків між кількісними змінними використано метод головних компонент (Principal component analysis). Критичний рівень значимості для перевірки статистичних гіпотез у дослідженні приймали рівним 0,05 .

\section{Результати}

Аналіз морфометричних і алометричних параметрів культивованих in vitro рослин виду G. lutea, які репрезентують генофонд його двох природних (г. Шешул-Павлик, п. Лемська) та однієї інтродукованої популяції (г. Пожижевська) показав, що інтенсивність їх ростових процесів і розвиток значною мірою залежать від спектрального складу світла та інтенсивності його потоку в ділянці ФАР.

У природному середовищі нижні листки G. lutea утворюють розетку, а верхні - стеблообгортні. Культивування in vitro ocoбин цього виду в умовах контролю за низької інтенсивності освітлення та збільшеної у спектрі частки хвиль Ес та Ез діапазонів викликає зміни їх габітусу. Це проявляється у не характерному для інтактних рослин видовженні міжвузлів, значному витягуванні стебел і утворенні дрібних довгочерешкових листків (рис. 18). Низька також біопродуктивність рослин контрольної групи всіх досліджених популяцій, про що свідчать показники фітомаси їх надземних органів і площі листкової поверхні, які у 2,9-3,7 раза (у випадку г. Пожижевська), 2,0-3,4 (п. Лемська), 2,5-3,7 раза (г. Шешул-Павлик) нижча порівняно $з$ першим варіантом СК і у 2,9-5,1 раза (г. Пожижевська), 2,7-5,7 (п. Лемська), 3,1-5,5 раза (г. Шешул-Павлик) - із другим варіантом досліду (табл. 1).

У рослин контролю найгірше, порівняно $з$ обома варіантами СК, розвивається коренева система та утворюється тонша на 18 $52 \%$ листкова пластинка. Низькі й величини фотосинтетичного зусилля, а також показники, що характеризують потужність роз- витку листкової поверхні (LAR). Відмінність контрольних рослин достовірно не значна лише від параметра SLA рослин першого варіанта СК (у випадку г. Пожижевська та г. Шешул-Павлик); за іншими параметрами рослини контрольної групи статистично достовірно (Р <0,001) відрізняються від обох варіантів досліду.

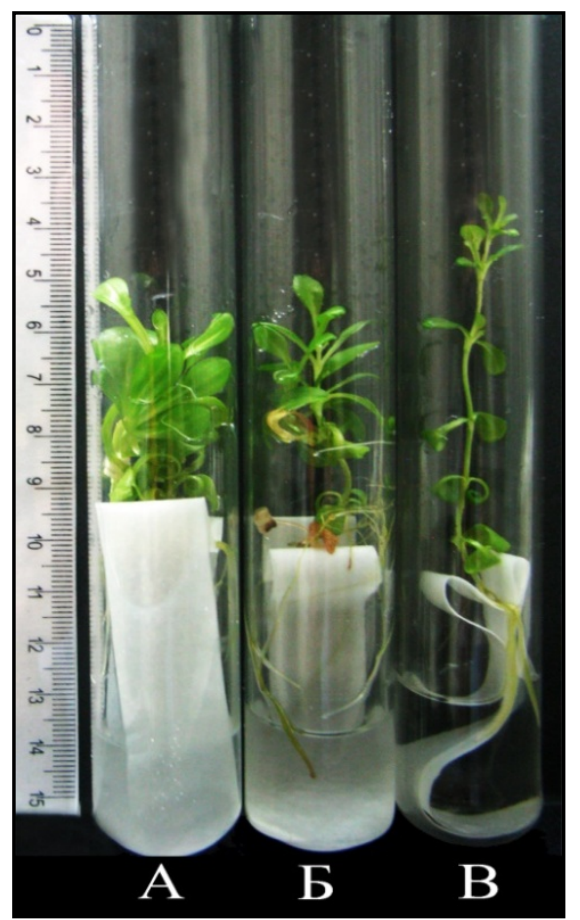

Рис. 1. Зміна габітусу культивованих in vitro рослин G. lutea популяції г. Шешул-Павлик за різних світлових режимів їх вирощування: $A$ - другий варіант світлової корекції; $E$ - перший варіант світлової корекції; $B$ - контроль

\section{Таблиця 1}

Зміна морфометричних і алометричних параметрів культивованих in vitro рослин G. lutea з різних популяцій залежно від джерела світла та інтенсивності світлового потоку $\left(\mathrm{BT} / \mathrm{M}^{2}\right)$ в області $\Phi$ АР, $(\mathrm{n}=10, \mathrm{x} \pm \mathrm{SD})$

\begin{tabular}{|c|c|c|c|c|c|c|c|c|c|}
\hline Варіант & $\mathrm{NL}$, шт & LS, cm & LIN, cM & WR, мг & WS, MT & $\mathrm{WP}, \mathrm{M \Gamma}$ & WL, $\mathrm{M \Gamma}$ & $\mathrm{ALI}, \mathrm{cm}^{2}$ & LSR, $\mathrm{M \Gamma} / \mathrm{M \Gamma} \quad \mathrm{LAR}, \mathrm{cm}^{2} / \mathrm{M \Gamma}$ SLA, $\mathrm{cm}^{2} / \mathrm{Mr} \quad \mathrm{LWR}, \mathrm{M \Gamma} / \mathrm{M \Gamma}$ \\
\hline \multicolumn{10}{|c|}{ Рослини з г. Пожижевська } \\
\hline Контроль & $10,6 \pm 1,9^{b}$ & $9,1 \pm 2,1^{\mathrm{a}}$ & $1,7 \pm 0,1^{\mathrm{a}}$ & $12,1 \pm 1,3^{\mathrm{c}}$ & $87,4 \pm 10,8^{b}$ & $99,4 \pm 12,1^{b}$ & $31,8 \pm 4,8^{c} \quad 2,7 \pm 0,4^{c}$ & $0,26 \pm 0,03^{\mathrm{c}}$ & $7,24 \pm 0,18^{\mathrm{a}} \quad 0,026 \pm 0,001^{\mathrm{c}} 0,085 \pm 0,002^{\mathrm{a}} 0,32 \pm 0,01^{\mathrm{c}}$ \\
\hline Варіант 1 & $12,4 \pm 1,6^{\mathrm{a}}$ & $5,6 \pm 0,7^{b}$ & $0,9 \pm 0,1^{\mathrm{b}}$ & $45,3 \pm 7,3^{b}$ & $253,7 \pm 41,3^{2}$ & $299,0 \pm 48,6$ & $111,3 \pm 5,9^{\mathrm{b}} 8,0 \pm 1,2^{\mathrm{b}}$ & $0,64 \pm 0,06^{\mathrm{b}}$ & $5,59 \pm 0,11^{\mathrm{b}} 0,026 \pm 0,001^{\mathrm{b}} 0,072 \pm 0,002^{\mathrm{b}} 0,34 \pm 0,01^{\mathrm{b}}$ \\
\hline Варіант 1 & $10,3 \pm 1,3^{b}$ & $2,7 \pm 0,4^{c}$ & $0,6 \pm 0,1^{\mathrm{c}}$ & $54,5 \pm 9,6^{\mathrm{a}}$ & $255,2 \pm 16,7^{2}$ & $301,9 \pm 35,4^{2}$ & $160,9 \pm 18,3^{\mathrm{a}} 9,1 \pm 0,7^{\mathrm{a}}$ & $0,89 \pm 0,07^{\mathrm{a}}$ & $4,62 \pm 0,37^{\mathrm{c}} 0,029 \pm 0,002^{\mathrm{a}} 0,056 \pm 0,003^{\mathrm{c}} 0,53 \pm 0,02^{\mathrm{a}}$ \\
\hline \multicolumn{10}{|c|}{ Рослини з п. Лемська } \\
\hline Контроль & $10,7 \pm 1,7^{b}$ & $9,4 \pm 1,7^{\mathrm{a}}$ & $1,8 \pm 0,1^{\mathrm{a}}$ & $11,3 \pm 0,8^{\mathrm{c}}$ & $84,5 \pm 4,8^{b}$ & $95,8 \pm 5,6^{b}$ & $29,2 \pm 2,3^{c} \quad 2,6 \pm 0,2^{c}$ & $0,24 \pm 0,02^{\mathrm{c}}$ & $7,48 \pm 0,18^{\mathrm{a}} 0,024 \pm 0,001^{\mathrm{c}} 0,087 \pm 0,002^{\mathrm{a}} 0,30 \pm 0,01^{\mathrm{c}}$ \\
\hline Варіант 1 & $12,8 \pm 1,5^{\mathrm{a}}$ & $4,5 \pm 0,5^{\mathrm{b}}$ & $0,6 \pm 0,1^{\mathrm{b}}$ & $39,1 \pm 5,1^{\mathrm{b}}$ & $222,0 \pm 35,9^{2}$ & $261,1 \pm 21,6^{a}$ & $85,9 \pm 10,7^{\mathrm{b}} 6,4 \pm 0,5^{\mathrm{b}}$ & $0,48 \pm 0,05^{\mathrm{b}}$ & $5,68 \pm 0,10^{\mathrm{b}} 0,026 \pm 0,001^{\mathrm{b}} 0,071 \pm 0,010^{\mathrm{b}} 0,33 \pm 0,02^{\mathrm{b}}$ \\
\hline Варіант 2 & $10,5 \pm 0,9^{\mathrm{b}}$ & $2,5 \pm 0,2^{\mathrm{c}}$ & $0,5 \pm 0,1^{\mathrm{c}}$ & $64,5 \pm 6,7^{\mathrm{a}}$ & $224,2 \pm 21,8^{2}$ & $287,7 \pm 27,9^{\mathrm{a}}$ & $145,3 \pm 13,5^{\mathrm{a}} 9,7 \pm 0,6^{\mathrm{a}}$ & $0,9 \pm 0,06^{\mathrm{a}}$ & $3,48 \pm 0,13^{\mathrm{c}} 0,033 \pm 0,001^{\mathrm{a}} 0,065 \pm 0,001^{\mathrm{c}} 0,50 \pm 0,01^{\mathrm{a}}$ \\
\hline \multicolumn{10}{|c|}{ Рослини з г. Шешул-Павлик } \\
\hline Контроль & $10,4 \pm 1,5^{\mathrm{a}}$ & $9,8 \pm 1,4^{\mathrm{a}}$ & $1,9 \pm 0,1^{\mathrm{a}}$ & $10,2 \pm 1,7^{\mathrm{c}}$ & $77,6 \pm 12,9^{\mathrm{b}}$ & $88,5 \pm 13,6^{\mathrm{b}}$ & $24,4 \pm 3,2^{\mathrm{c}} 2,3 \pm 0,1^{\mathrm{c}}$ & $0,22 \pm 0,05^{\mathrm{c}}$ & $7,62 \pm 0,26^{\mathrm{a}} 0,025 \pm 0,002^{\mathrm{c}} 0,092 \pm 0,001^{\mathrm{a}} 0,28 \pm 0,02^{\mathrm{c}}$ \\
\hline антт 1 & $12,2 \pm 1,8^{\mathrm{a}}$ & $6,2 \pm 0,8^{\mathrm{b}}$ & $1,0 \pm 0,1^{\mathrm{b}}$ & $37,9 \pm 3,1^{\mathrm{b}}$ & $220,6 \pm 30,6^{2}$ & $258,5 \pm 35,8^{\mathrm{a}}$ & $80,9 \pm 12,5^{\mathrm{b}} 6,9 \pm 0,2^{\mathrm{b}}$ & $0,56 \pm 0,03^{\mathrm{b}}$ & $5,81 \pm 0,10^{\mathrm{b}} 0,026 \pm 0,001^{\mathrm{b}} 0,083 \pm 0,001^{\mathrm{b}} 0,31 \pm 0,01^{\mathrm{b}}$ \\
\hline Варіант 2 & $11,6 \pm 1,7^{\mathrm{a}}$ & $3,7 \pm 0,5^{c}$ & $0,6 \pm 0,1^{\mathrm{c}}$ & $44,7 \pm 5,8^{\mathrm{a}}$ & $236,5 \pm 37,9^{\circ}$ & $281,2 \pm 38,6$ & $134,7 \pm 24,1^{\mathrm{a}} 8,6 \pm 0,4^{\mathrm{a}}$ & $0,72 \pm 0,08^{\mathrm{a}}$ & $5,32 \pm 0,26^{\mathrm{c}} 0,029 \pm 0,001^{\mathrm{a}} 0,062 \pm 0,002^{\mathrm{c}} 0,48 \pm 0,02^{\mathrm{a}}$ \\
\hline
\end{tabular}

Застосування ламп ЛХБ у першиму варіанті СК дозволило підвищити інтенсивність світлового потоку до 44,0 Вт/ $\mathrm{m}^{2}$, а також скоригувати спектральний склад світла, зменшивши у ньому частку хвиль синього діапазону та збільшивши частку хвиль червоного спектра порівняно 3 контролем. При цьому частка хвиль зеленого спектра (500-600 нм) залишилася майже незмінною. Аналіз габітусу та ростових процесів показав, що такі світлові умови культивування сприятливіші для G. lutea. Висота стебел особин усіх досліджених популяцій в 1,6 раза (г. Пожижевська, г. Шешул-Павлик) та 2,1 раза (у випадку п. Лемська) зменшується порівняно 3 контролем (рис. 1б). Водночас поліпшуються параметри, що визначають продуктивність рослин: фітомаса кореневої системи та надземної частини, площа листкової по- верхні та відносної площі, що припадає на один листок. Слід зазначити, що вибірка рослин усіх популяцій першого варіанта СК за показниками загальної сирої маси та маси надземної частини статистично достовірно не відрізняється від другого варіанта СК. Цей світловий режим стимулює утворення більшої кількості листків у розрахунку на одну рослину та активує розвиток пазушних меристем. Однак за результатами аналізу даних алометричних параметрів ефективність утворення листкової поверхні ще доволі низька, що позначається на фотосинтетичному зусиллі рослин (табл. 1). Корекція світлового фону контролю лампами ЛХБ та ФЛ (другий варіант), як і у випадку першого варіанта СК, дозволила підвищити освітленість до 3000 лк, значно збільшити інтенсивність світлового потоку $\left(135,4 \mathrm{BT} / \mathrm{m}^{2}\right)$ та оптимізу- 
вати спектральний склад. Зменшилася в 1,4 раза частка хвиль синього та в 1,3 раза-зеленого діапазонів, а червоного - збільшилася у 2,5 раза. Аналіз морфометричних і алометричних показників показав, що у G. lutea в умовах другого варіанта CK порівняно 3 контролем більше ніж утричі скорочується довжина міжвузлів; в 1,6-1,7 раза зростають величини фотосинтетичного зусилля, у 5,5-9,9 раза збільшується маса листків, у 3,3-3,8 раза - загальна площа листкової поверхні (рис. 1a). Значно краще розвивається коренева система, про що свідчать показники відношення біомаси пагона до біомаси кореневої системи (LSR).

Серед багатьох факторів, що впливають на інтенсивність фотосинтезу, i, як наслідок, на біосинтетичні процеси та продуктивність рослин, найважливіша роль у пігментної системи. Як показують наші дослідження, пігментний комплекс пластид культивованих in vitro рослин G. lutea динамічно реагує на зміну режиму освітлення (табл. 2).
Найвищі показники хлорофілів $a, b$ і каротиноїдів характерні для рослин контрольної групи (табл. 2). Зміна спектрального складу та інтенсивності освітлення у першому варіанті СК знижує концентрації пігментів в 1,2-1,5 раза як за відношенням до контрольної групи, так і у другому варіанті СК. Ще більших змін зазнає пігментний комплекс рослин другого варіанта СК: вміст хлорофілу $a$ і каротиноїдів у даному випадку достовірно значимо не відрізняється від контролю, однак концентрація хлорофілу $b$ нижча. Це спричиняє збільшення величини відношення хлорофіл $a$ / хлорофіл $b$ у цьому варіанті СК порівняно з контролем і першим варіантом СК. Водночас, за показниками відношень хлорофіл $a$ / хлорофіл $b$ та хлорофіл $b$ / каротиноїди рослини другого варіанта СК найбільше наближені до G. lutea iз природних місць росту (неопубліковані дані).

\section{Таблиця 2}

Зміна вмісту та співвідношення пігментів у культивованих in vitro рослин G. lutea з різних популяцій

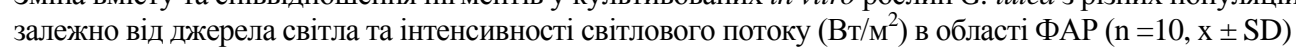

\begin{tabular}{|c|c|c|c|c|c|c|c|}
\hline $\begin{array}{c}\text { Умови } \\
\text { досліду }\end{array}$ & $\begin{array}{c}\text { Chl } a, \mathrm{мг} / 100 \text { г } \\
\text { сирої маси }\end{array}$ & $\begin{array}{c}\text { Chl } b, \text { мг / } 100 \text { г } \\
\text { сирої маси }\end{array}$ & $\begin{array}{c}\text { Carot, мг/100 г } \\
\text { сирої маси }\end{array}$ & Chl $a / b$ & Chl $a+b / c a r$ & Chl $a$ / car & Chl $b / c a r$ \\
\hline \multicolumn{8}{|c|}{ Рослини з г. Пожижевська } \\
\hline Контроль & $109,5 \pm 16,8^{\mathrm{a}}$ & $29,0 \pm 2,4^{\mathrm{a}}$ & $44,1 \pm 7,4^{\mathrm{a}}$ & $3,78 \pm 0,05^{b}$ & $3,12 \pm 0,14^{b}$ & $2,49 \pm 0,08^{b}$ & $0,65 \pm 0,03^{b}$ \\
\hline Варіант 1 & $80,5 \pm 15,0^{b}$ & $21,5 \pm 3,0^{b}$ & $32,4 \pm 3,5^{b}$ & $3,76 \pm 0,14^{b}$ & $3,13 \pm 0,14^{\mathrm{b}}$ & $2,48 \pm 0,11^{\mathrm{b}}$ & $0,66 \pm 0,03^{b}$ \\
\hline Варіант 2 & $103,7 \pm 16,6^{\mathrm{a}}$ & $22,5 \pm 3,1^{b}$ & $38,3 \pm 3,1^{\mathrm{ab}}$ & $4,59 \pm 0,08^{\mathrm{a}}$ & $3,31 \pm 0,13^{\mathrm{a}}$ & $2,71 \pm 0,13^{\mathrm{a}}$ & $0,59 \pm 0,04^{\mathrm{a}}$ \\
\hline \multicolumn{8}{|c|}{ Рослини з п. Лемська } \\
\hline Контроль & $102,5 \pm 7,8^{\mathrm{a}}$ & $26,1 \pm 2,0^{\mathrm{a}}$ & $36,3 \pm 2,4^{\mathrm{a}}$ & $3,87 \pm 0,14^{b}$ & $3,48 \pm 0,12^{\mathrm{a}}$ & $2,82 \pm 0,07^{\mathrm{a}}$ & $0,72 \pm 0,02^{\mathrm{a}}$ \\
\hline Варіант 1 & $86,3 \pm 7,2^{\mathrm{b}}$ & $22,2 \pm 1,9^{b}$ & $35,4 \pm 2,7^{\mathrm{a}}$ & $3,90 \pm 0,06^{\mathrm{b}}$ & $3,06 \pm 0,09^{b}$ & $2,43 \pm 0,07^{c}$ & $0,63 \pm 0,02^{\mathrm{b}}$ \\
\hline Варіант 2 & $100,8 \pm 9,1^{\mathrm{a}}$ & $21,0 \pm 2,0^{b}$ & $38,1 \pm 3,6^{\mathrm{a}}$ & $4,80 \pm 0,15^{\mathrm{a}}$ & $3,20 \pm 0,09^{b}$ & $2,65 \pm 0,17^{\mathrm{b}}$ & $0,56 \pm 0,04^{\mathrm{c}}$ \\
\hline \multicolumn{8}{|c|}{ Рослини з г. Шешул-Павлик } \\
\hline Контроль & $111,3 \pm 14,04^{\mathrm{a}}$ & $26,76 \pm 3,9^{\mathrm{a}}$ & $35,8 \pm 4,7^{b}$ & $4,18 \pm 0,22^{\mathrm{a}}$ & $3,90 \pm 0,18^{\mathrm{a}}$ & $3,14 \pm 0,17 a$ & $0,75 \pm 0,03^{\mathrm{a}}$ \\
\hline Варіант 1 & $74,0 \pm 9,63^{\mathrm{b}}$ & $20,35 \pm 3,5^{b}$ & $27,6 \pm 3,7^{c}$ & $3,72 \pm 0,10^{\mathrm{b}}$ & $3,40 \pm 0,11^{\mathrm{b}}$ & $2,68 \pm 0,9^{\mathrm{b}}$ & $0,72 \pm 0,03^{b}$ \\
\hline Варіант 2 & $100,43 \pm 4,97^{\mathrm{a}}$ & $23,66 \pm 1,0^{\mathrm{ab}}$ & $36,8 \pm 3,2^{\mathrm{a}}$ & $4,30 \pm 0,21^{\mathrm{a}}$ & $3,41 \pm 0,16^{b}$ & $2,77 \pm 0,13^{\mathrm{b}}$ & $0,65 \pm 0,26^{\mathrm{c}}$ \\
\hline
\end{tabular}

Примітки: ${ }^{\text {a, b, с }}$ - однакові латинські букви означають статистично незначущі розбіжності середніх у ряді за критерієм Tьюкі (HSD); Сhl $a-\mathrm{xлоро-}$ філ $a$, Chl $b$ - хлорофіл $b$, Carot - каротиноїди, Chl $a / b-$ відношення хлорофілу $a$ до хлорофілу $b$, Chl $a+b /$ car - відношення суми хлорофілів ( $a+b)$ до каротиноїдів, Chl $a$ / car - відношення хлорофілу $a$ до каротиноїдів, Chl $b$ /car - відношення хлорофілу $b$ до каротиноїдів.

Міжпопуляційне варіювання показників відношення суми $(a+b)$ хлорофілів до каротиноїдів, а також хлорофілу а до каротиноїдів, не дозволяє чітко з'ясувати ступінь їх залежності від світлових умов культивування. Проте, як видно з таблиці 2, відношення частки хлорофілу $b$ до каротиноїдів у пігментному комплексі рослин найвище у контролі. У міру зростання інтенсивності світлового потоку та частки хвиль Еч діапазону у спектрі випромінювання відносний вміст хлорофілу $b$ у листках зменшується, що свідчить про зміну співвідношення пігмент-білкових комплексів, яка може виявитись оптимальною, оскільки наближена до природної популяції. Необхідно зазначити, що, на відміну від ростових параметрів, ступінь статистично значимої міжгрупової достовірної різниці у випадку пігментного складу дещо менший, особливо у випадку вибірок рослин із г. Пожижевська і п. Лемська. Для рослин г. Шешул-Павлик ступінь статистично достовірної різниці вмісту пігментів та їх співвідношення коливається в межах від $\mathrm{P}<0,001$ до $\mathrm{P}<0,05$.

Вміст пігментів у фотосинтетичному апараті, ростові процеси детермінуються генотипом рослин. $Є$ певні міжпопуляційні відмінності показників досліджених параметрів як у рослин контрольної групи, так і обох варіантів СК (табл. 1, 2). Однак виявлені тенденції щодо зміни габітусу, морфометричних, алометричних параметрів та пігментного складу залежно від світлового режиму культивування in vitro характерні для вибірок рослин усіх трьох досліджених популяцій. Можна припустити, що це загальна видоспецифічна реакція $G$. lutea на зміну інтенсивності випромінювання та його спектрального складу.

Для встановлення кореляційних зв'язків між ростовими процесами, пігментним складом G. lutea та світловими режимами їх вирощування in vitro за значної дисперсії отриманих показників застосовано метод головних компонент. Це дозволило зменшити розмірність отриманих даних і сформувати їх у спеціальні факторіальні комплекси - головні компоненти (РC 1, РС 2), що більш інформативно відображають характер впливу світлового режиму на перебіг морфофізіологічних процесів у культивованих in vitro рослин $G$. lutea. Як видно з рисунка 2, змінні (Dim $1 \mathrm{i}$ Dim 2), що корелюють 3 відповідними компонентами РC 1 і РC 2 враховують 73,5\% дисперсії вимірюваних показників у контрольній групі культивованих in vitro G. lutea та двох варіантах СК досліджених популяцій. При цьому Dim 1 вичерпує 57,7\%, а Dim2 - 15,8\% сумарної дисперсії.

Основний внесок у визначення стану культивованих рослин за Dim 1 дають показники, які характеризують приріст біомаси та збільшення площі листкової поверхні рослин, а також співвідношення пігментів у реакційних центрах і світлозбиральних комплексах фотосистем. Змінна $\operatorname{Dim} 2$ об'єднує параметри, що відображають залежність кількості листків та вмісту хлорофілу $a$, хлорофілу $b$, каротиноїдів від світлових умов культивування.

Характер розташування параметрів у просторі головних компонент дозволив виділити три групи показників (кластерів), що детерміновані певним світловим режимом і відповідають контролю $(A)$, першого варіанта СК $(b)$, другого варіанта СК $(B)$ (рис. 2). При цьому в межах групи усі параметри між собою корелюють позитивно; між діаметрально протилежно розташованими параметрами спостерігається негативна кореляція.

Як видно з рисунка 2, кластер $A$ включає параметри L, LIN, LSR, SLA, відношення хлорофіл $b$ / каротиноїди. Це підтверджує той факт, що умови контролю найбільше впливають на зміну довжини (L, LIN) осьових органів. Тому з цими параметрами тісно пов'язаний показник LSR, який визначає відношення біомаси надземної частини до біомаси кореня. Сильним стохастичним зв'язком умови контролю пов'язані з показниками товщини листкової пластинки (SLA) та відношенням хлорофілу $b$ до каротиноїдів ( $b$ / car) у світлозбиральному комплексі ФС II. Прина- 
лежність параметра відношення хлорофіл $b$ / каротиноїди до області кластера контролю дозволяє чіткіше інтерпретувати дані таблиці 2 та підтвердити сильний стохастичний зв'язок цієї величини лише з режимом освітлення контролю.

Застосування методу головних компонент дозволило підтвердити інші наші попередні висновки: що світлові умови першого варіанта СК сприяють збільшенню кількості листків у рослин; що між групою величин LWR, SLA, відношення хлорофіл $а$ / хлорофіл $b$ та режимом першого варіанта СК відсутній кореляційний зв'язок. Незначне перекривання областей кластерів Б і В означає, що на показники продуктивності рослин (WP, WS, WR, $\mathrm{WL}, \mathrm{A}, \mathrm{ALI})$ світловий режим першого варіанта менше впливає, ніж ми це припускали під час аналізу усереднених даних таблиці 1.

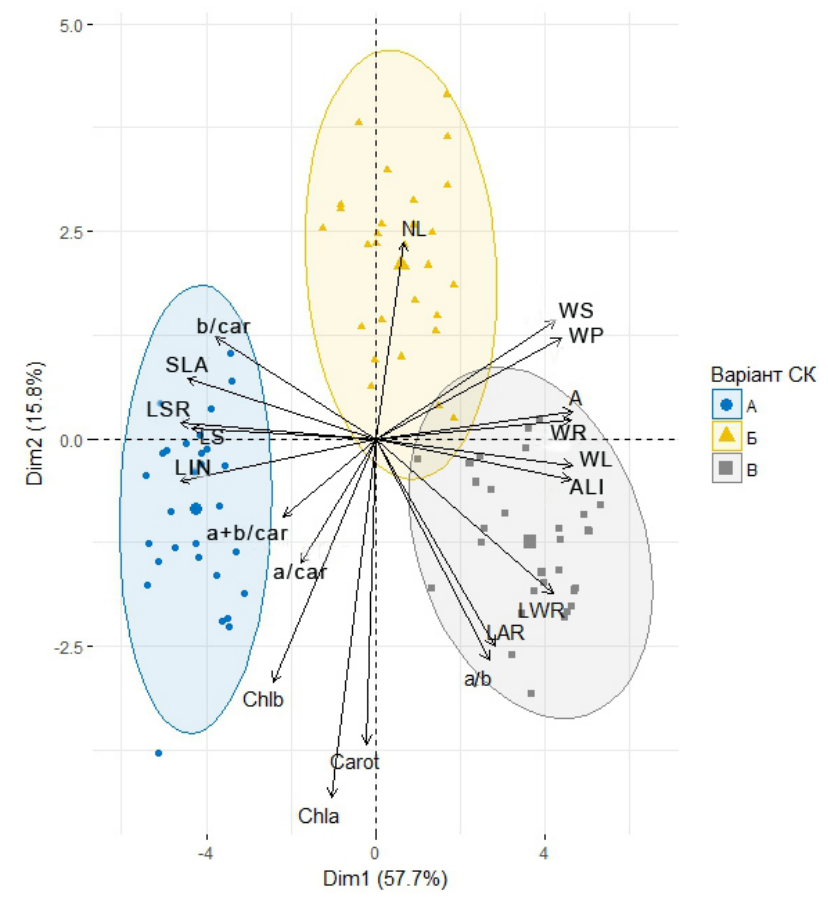

Рис. 2. Зв'язки морфометричних, алометричних параметрів та пігментного комплексу культивованих in vitro рослин із популяцій (г. Пожижевська, г. Шешул-Павлик, п. Лемська)

G. lutea зі світловими режимами їх вирощування:

$A$ - контроль; $D$ - перший варіант CK; $B$ - другий варіант СК: позначення - див. табл. 1, 2

Tiсне же групування величин WP, WS, WR, WL, A, ALI, LWR, SLA, хлорофіл $a$ / хлорофіл $b$ у межах області кластера B вказує як на позитивну кореляцію між ними, так і на сильний стохастичний зв’язок між цими параметрами та світловим режимом цього варіанта.

Вище ми зазначали складність виявлення набору чинників, що впливають на пігментну систему пластид культивованих in vitro G. lutea. Застосування методу головних компонент дозволило точніше з'ясувати характер залежності показників як одного від іншого, так і від світлових умов. Особливості розташування у двовимірній площині величин, що стосуються вмісту пігментів (хлорофілу $a, b$, каротиноїдів), а також відношень суми хлорофілів $(a+b) /$ каротиноїдів $(a+b /$ car $)$ і хлорофілу $a$ / каротиноїдів ( $a$ / car) вказують на існування слабкого позитивного кореляційного зв'язку між ними. Вектор же їх тяжіння до проекцій головних компонент РС 1 і РС 2 визначає ступінь кореляційного зв'язку $з$ режимами освітлення контрольної та дослідних груп рослин. Тому розташування показників хлорофілу $a$ i каротиноїдів в області нульової позначки головної компоненти РС 1 означає, що на їх величини майже однаково впливають як умови контролю, так і другого варіанта СК. Водночас відхилення їх векторів (Chl $a$, Carot) у бік контрольної групи вказує на дещо більшу домінуючу роль саме цього світлового режиму. Характер направленості векторів хлорофілу $а$ та каротиноїдів відносно області кластера першого варіанта означає, що між ними існує негативний кореляційний зв'язок.

Вектор направленості величини хлорофіл $b(\mathrm{Chl} b)$ також вказує на їі більший стохастичний зв'язок зі світловим режимом контрольної групи, що зумовлено специфікою роботи світлозбирального комплексу ФС II за таких умов. Застосування методу головних компонент дозволило виявити кореляційні зв'язки 3 режимами освітлення величин, що характеризують відношення як суми хлорофілів $(a+b)$ до каротиноїдів, так і хлорофілу $a$ до каротиноїдів. Як видно з рисунка 2, напрям векторів цих величин свідчить про їх сильніший кореляційний зв'язок із контрольною групою, ніж із дослідними варіантами СК.

\section{Обговорення}

Аналіз отриманих експериментальних даних дозволяє припустити, що інтенсивність ростових процесів і морфогенез культивованих in vitro рослин $G$. lutea за різних умов освітлення контролюються складними механізмами, які залежать не лише від особливості функціонування фотосинтетичної системи. Це пов'язано $з$ тим, що світло здатне переключати механізми ендогенної регуляції та реалізувати відповідні програми морфогенезу. Його фізіологічне значення для рослин не обмежується лише фотосинтезом, а поширюється на численні системи контролю за ростом і розвитком організму (Karnachuk et al., 1990; Kaiserli \& Chory, 2016). При цьому доведено, що ріст рослин визначає одночасне поєднання трьох параметрів: якості світла, його інтенсивності та тривалості дії (Folta \& Childers, 2008).

Сучасними дослідженнями доведено, що до системи фоторегуляції морфогенезу входять рецептори та трансдуктори світлового сигналу: фітохроми, які поглинають хвилі Еч і дальнього червоного діапазонів; криптохроми, фототропіни та нефотосинтетичні каротини - ультрафіолет (УФ А, УФ В) та Ес; суперхром (неохром) - область Ес і Еч (Wang \& Deng, 2002).

Нині немає єдиного погляду щодо механізмів трасляції світлового сигналу в клітині. Однак схиляються до думки, що поглинене сенсорними пігментами світло не лише спричинює синтез макроергічних хімічних сполук через реалізацію фотосинтетичної функції, а також утворює сигнал, здатний передаватися по компонентах цитозолю та геному, активізуючи цитозольні компоненти, експресію генів COP, DET, FUS, продукти яких беруть участь у регуляції процесів морфогенезу (Franklin et al., 2005). При цьому відбувається зміна ендогенного гормонального балансу рослини, який контролює як процеси росту та розвитку, так і роботу фотосинтетичного апарату. Припускають, що фоторегуляторні системи, які відповідають за фотосинтез і морфогенез, можуть мати як спільні фоторецептори, так і специфічні для кожної з них (Lau \& Deng, 2010).

Складність взаємодії багаторівневих регуляторних механізмів, що інтегрують процеси росту та фотосинтезу не дозволяє на даний час з'ясувати всі кореляційні зв'язки між структурнофункціональними характеристиками фотосинтетичного апарату та продуктивністю рослин (Kabashnikova, 2011). Однак припускають, що механізми, які відповідають за ріст рослин, являють собою регуляторні системи першого порядку, а механізми, що визначають стан пігментної системи та інтенсивність перебігу фотосинтетичних реакцій, $є$ регуляторними системами другого порядку (Nemoikyna, 2003; Zavoruev et al., 2011).

Застосування такого підходу дозволяє пояснити існуючу невідповідність між високим вмістом пігментів хлорофілу $a$, хлорофілу $b$ і каротиноїдів у фотосинтетичному апараті та загальною низькою продуктивністю рослин G. lutea контрольної групи. За низьких значень інтенсивності освітлення рослини фактично не здатні поглинати хвилі Еч діапазону (Dong et al., 2014). Низка регуляторних фітохромів поглинає світло у ближньому та дальньому червоному діапазонах і регулює синтез вуглеводів у процесі фотосинтезу, тому перебіг морфофізіологічних реакцій може визначати низька інтенсивність світлового потоку Еч i 
висока частка хвиль Ес і Ез діапазонів (із перевагою зеленого світла у спектрі ЛД ламп).

Збільшення у спектрі частки синього діапазону змінює механізми регуляції функціонування так званої «системи високої енергіï» (Margitay, 2006) та модифікації пігментного складу фотосинтетичного апарату. Це супроводжується зростанням концентрацій хлорофілу $a$, хлорофілу $b$ і каротиноїдів у рослин контролю, оскільки у хлорофілу $a$ поглинання в синьому діапазоні в 1,3 раза більше, ніж у червоному, а у хлорофілу $b$ - утричі (Margitay, 2006). Каротиноїди теж мають максимуми поглинання в Ес діапазоні. За нижчої інтенсивності освітлення вони виконують функцію додаткових світлозбиральних пігментів і їх частка збільшується у світлозбиральному комплексі ФС II (Havaux et al., 2000; Bailey et al., 2004; Syvash et al., 2016). Проте ефективність передачі енергії від каротиноїдів до хлорофілів залежить як від виду каротиноїдів, так і від їх положення у фотосинтетичному апараті та не перевищує 35-90\%, тоді як ефективність передачі енергії в антенних комплексах хлорофілу становить 100\% (Caffarri et al., 2007).

Такі зміни структури у світлозбиральному комплексі ФС II G. lutea контрольної групи мали б компенсувати для них нестачу світла та, як результат, поліпшити продуктивність. Проте різні спектри світла та різна його інтенсивність можуть здійснювати протилежний вплив на один і той самий фізіологічний процес (Dou et al., 2017). За даними багатьох досліджень (Vicente \& Garcia, 1981; Tanada, 1984; Golovatskaya, 2005; Folta \& Maruhnich, 2007), трансдукція світлових сигналів Ез і Ес діапазонів здійснюється не лише фотосинтетичними пігментами, фітохромами та криптохромами, а й додатковими фоторецепторами, що працюють на нижчих або вищих енергіях випромінювання. Це активізує сітку вторинних посередників та гормональну систему регуляції рослини й може зменшити концентрацію ендогенної індолілоцтової кислоти (ІОК) і збільшити вміст деяких форм вільних гіберелінів (Nemoykina \& Karnachuk, 2002). Згідно 3 дослідженнями Voskresenskaya (1987), Ес спектр стимулює білковий обмін, а Еч - вуглеводний. Тому сумація ефектів впливу хвиль Ес та Ез діапазонів у спектрі контролю, ймовірно, здатна змінити перебіг метаболічних процесів та природний гормональний баланс рослин контрольної групи G. lutea всіх досліджених популяцій. Це запускає специфічні реакції фотоморфогенезу, які спричиняють слабкий розвиток кореневої системи, витягування стебел, утворення дрібних листків із тонкою листковою пластинкою та загальну низьку продуктивність G. lutea в контролі. Подібні результати отримані Cope \& Bugbee (2013) під час вивчення змін ростових параметрів рослин Raphanus sativus за впливу низької інтенсивності світла з високою часткою хвиль Ес i Ез. Як наслідок, такі особини мають слабкий адаптаційний потенціал. Це підтверджують наведені нами дані щодо їх значної летальності на першому та другому роках життя після перенесення у природу.

Тому додаткове використання ламп ЛХБ для корекції світлового режиму культивування G. lutea (перший варіант СК) дозволило підвищити інтенсивність світлового потоку, збільшити поглинання фотосинтетичним апаратом фотонів Ек спектра та, певною мірою, збалансовувати регуляторні системи, що контролюють ростові процеси та фотосинтез G. lutea. Це підтверджують результати морфометричного аналізу та пігментного складу рослин цього варіанта СК. Зниження вмісту всіх пігментів, порівняно з контролем, ймовірно, означає перебування рослин у задовільніших світлових умовах. Однак низьке відношення хлорофіл $a$ / хлорофіл $b$ у хлоропластах вказує на ще відносно високу концентрацію хлорофілу $b$ у світлозбиральному комплексі ФC II (Leong \& Anderson, 1984; Matsuda et al., 2007).

Це дозволяє припустити, що світлові умови першого варіанта СК ще не повною мірою відповідають фізіологічному оптимуму світлозабезпечення, необхідному для повноцінного функціонування фотосинтетичного апарату рослин G. lutea. На користь цього свідчать низькі показники розвитку фотосинтетичного апарату (табл. 2) в особин цього варіанта досліду. Проте такі світлові умови, порівняно з контролем та другим варіантом CK, ініціювали утворення у рослин G. lutea всіх досліджених популяцій більшої кількості листків та мікроклональне розмноження. Подібні результати отримали Nemoykyna \& Karnachuk (2002) під час культивування in vitro під лампами «білого спектра» рослин виду Yucca elephantipes R. За переважання у спектрі хвиль Ес діапазону збільшується ефект впливу екзогенного цитокініну, доданого у живильне середовище для культивування (Nemoykyna \& Karnachuk, 2002). Імовірно, сумування спектрів ЛД і ЛХБ ламп посилило дію введеного до складу живильного середовища регулятора росту Кінетину, що не лише сприяло збільшенню кількості листків, а й активізувало ріст пазушних меристем $G$. lutea. Така оптимізація світлового режиму дозволяє збільшити коефіцієнт мікроклонального розмноження G. lutea без додаткового застосування більших концентрацій екзогенних регуляторів росту, що значно здешевлює процес отримання посадкового матеріалу.

Оптимізація спектрального складу в області ФАР штучного світла за рахунок підвищення частки хвиль Еч діапазону збалансовує регуляторні системи, що відповідають за ріст та фотосинтез (Nemoykyna \& Karnachuk, 2002). За таких умов у рослин не лише достатньо збільшується загальна площа листкової поверхні, а й спостерігається максимальний фотосинтез із одиниці іiі поверхні. Це зумовлено декількома причинами: червоне світло у діапазоні 600-640 нм має найвищий квантовий вихід для фіксації $\mathrm{CO}_{2}$, фотолізу води та виділення $\mathrm{O}_{2}$, тому підвищує ефективність роботи фотосинтетичного апарату (Hogewoning et al., 2013); оптимізація спектрального складу та інтенсивності освітлення врівноважує співвідношення фітогормонів та інгібіторів росту, що відображається на зміні швидкості росту та продуктивності рослин (Lau \& Deng, 2010).

Ці висновки підтверджують і результати наших експериментальних досліджень, оскільки додаткове застосування фітоламп у другому варіанті СК, які у своєму спектрі мають високу частку хвиль червоного діапазону, дозволило отримати максимальний приріст сирої біомаси не лише надземної, а й підземної частини у рослин G. lutea. Згідно з дослідженнями Karnachuk (2002), корекція «білого спектра» лампами «червоного спектра» в культивованих in vitro рослин збільшує концентрацію ендогенної ІОК, що сприяє їх швидшому укоріненню. Добре же розвинена коренева система одна 3 головних умов фізіологічної стабільності рослинного організму, оскільки завдяки збільшенню площі всмоктування кореневої системи тканин і органів рослини краще забезпечуються необхідною кількістю макро- та мікроелементів (Bao et al., 2014).

Оптимізація світлових умов культивування in vitro рослин G. lutea у другому варіанті СК позначилася й на загальному балансі фотосинтетичних пігментів, які містяться в реакційних центрах і світлозбиральних комплексах фотосистем. Рослини, фотосинтез яких відбувається в оптимальних умовах, у пластидах містять зазвичай високий пул хлорофілу $a$ (Leong \& Anderson, 1984; Walters, 2005). Як показали наші дослідження, вміст хлорофілу $a$, а також каротиноїдів у пластидах рослин G. lutea другого варіанта СК високий і достовірно значимо (за винятком г. ШешулПавлик) не відрізняється від контролю. Проте зниження концентрації хлорофілу $b$ у світлозбиральних комплексах вказує на перебування рослин у комфортних щодо світлозабезпечення умовах. Високий вміст каротиноїдів у даному випадку зумовлений їх фотозахисною функцією (Bailey et al., 2004; Lichtenthaler et al., 2007). Можна припустити, що високі концентрації пігментів у фотосинтетичному апараті культивованих in vitro рослин G. lutea другого варіанта СК забезпечать не лише більшу їх пластичність, а й швидший перехід від гетеротрофного до автотрофного живлення та кращу здатність особин адаптуватися до нестерильних умов ех vitro та in situ.

Зовнішній вигляд рослин G. lutea другого варіанта СК найбільше відповідає габітусу інтактних особин цього виду. Значно вкорочені міжвузля ускладнюють процедуру живцювання рослин in vitro. Тому доцільно використовувати світловий режим другого 
варіанта досліду лише на заключних етапах підготовки посадкового матеріалу G. lutea до перенесення в умови ex vitro та in situ.

На основі узагальнення експериментальних даних можна запропонувати схему оптимізації світлового режиму вирощування in vitro посадкового матеріалу G. lutea, яка передбачає двоетапне культивування: 1) мікроклональне розмноження та ріст рослин in vitro за світлових умов першого варіанта СК; 2) вкорінення отриманих пагонів за режиму освітлення другого варіанта СК.

\section{Висновки}

Морфогенез і біопродуктивність культивованих in vitro pocлин $G$. lutea не лише залежать від вмісту пігментів та їх співвідношення в реакційних центрах і світлозбиральних комплексах фотосистем, а й регулюються складнішими механізмами, здатними змінювати ендогенний фітогормональний баланс і перебіг метаболічних реакцій. Фотосинтетичний апарат культивованих in vitro рослин G. lutea за зміни спектрального складу світла та його інтенсивності упродовж 90 діб здатний повністю перебудуватися та змінити кількісне співвідношення пігментів, що позначається на інтенсивності його функціонування.

Отримані результати показали недоцільність культивування рослин G. lutea під лампами ЛД, оскільки такі світлові умови запускають специфічні реакції фотоморфогенезу, які викликають слабкий розвиток кореневої системи, витягування стебел, утворення дрібних листків із тонкою листковою пластинкою та загальної низької продуктивності рослин.

Виявлено ефективність впливу корекції спектрального складу та інтенсивності освітлення ламп ЛД лампами ЛХБ на процеси росту та розвитку in vitro рослин G. lutea. Зроблено припущення, що сумування спектрів ЛД і ЛХБ посилило дію екзогенного Кін, уведеного до складу живильного середовища. Це, у свою чергу, спричинило ініціювання росту пазушних меристем. Тому культивування in vitro рослин G. lutea в таких світлових умовах не лише поліпшує їх біопродуктивність порівняно із застосуванням лише лампи денного світла (контроль), а й дозволяє збільшити коефіцієнт мікроклонального розмноження без додаткового використання екзогенних регуляторів росту фітогормонів, що значно здешевлює процес отримання посадкового матеріалу. Показано ефективність застосування комбінації ламп ЛД, ЛХБ і фітоламп у співвідношенні 0,6 : $1: 1$, відповідно, для корекції світлового режиму вирощування рослин G. lutea на заключних етапах підготовки їх посадкового матеріалу до перенесення в умови ex vitro та in situ. Це пов'язано з тим, що підвищення частки хвиль Еч діапазону збільшує ефективність поверхні листків, вмісту фотосинтетичних пігментів, найбільшого приросту надземної та підземної частин. Припускаємо, що це забезпечить швидший перехід культивованих in vitro рослин G. lutea від гетеротрофного до автотрофного живлення, посилить їх адаптаційний потенціал і дозволить легше пристосуватися до нестерильних умов ех vitro та in situ.

Виявлені тенденції щодо зміни габітусу, морфометричних, алометричних параметрів та пігментного складу залежно від світлового режиму культивування in vitro характерні для вибірок рослин усіх трьох досліджених популяцій. Враховуючи ці дані та результати методу головних компонент, можна припустити, що це загальна видоспецифічна реакція G. lutea на зміну інтенсивності випромінювання та його спектрального складу.

Застосування дисперсійного аналізу та методу головних компонент дозволило точніше інтерпретувати результати дослідження. На основі отриманих результатів розроблено схему оптимізації світлового режиму вирощування in vitro рослин G. lutea для підвищення їх адаптаційного потенціалу та реалізувати завдання першого етапу багатоступінчастої технології стабілізації / реінтродукції популяцій цього виду на території Українських Карпат.

\section{References}

Bailey, S., Horton, P., \& Walters, R. G. (2004). Acclimation of Arabidopsis thaliana to the light environment: The relationship between photosynthetic function and chloroplast composition. Planta, 218, 793-802.

Banas, A. K., \& Gabrys, H. (2007). Influence of sugars on blue light-induced chloroplast relocations. Plant Signaling and Behavior, 2(4), 221-230.

Bao, Y., Aggarwal, P., Robbins II, N. E., Sturrock, C. J., Thompson, M. C., Tan, H. Q., Tham, C., Duan, L., Rodriguez, P. L., Vernoux, T., Mooney, S. J., Bennett, M. J., \& Dinneny, J. R. (2014). Plant roots use a patterning mechanism to position lateral root branches toward available water. Proceedings of the National Academy of Sciences of the United States of America, 111(25), 9319-9324.

Belokurova, V. B. (2010). Methods of biotechnology in system of efforts aimed at plant biodiversity preservation (Review). Cytology and Genetics, 44(3), 174-185.

Bidl, K. L. (1989). Fotosintez i bioproduktivnost': Metody opredelenija [Photosynthesis and bioproductivity: Methods of determination]. Ahropromizdat, Moscow (in Russian).

Bisht, S. S., Bisht, A. S., \& Chauhan, R. S. (2017). In-vitro mutagenesis induction to improve abiotic stress in tissue cultured plantlet of Picrohiza kurroa Royle ex. Benth: An endangered plant of Western Himalayas, India. Medicinal and Aromatic Plants, 6(2), 287.

Burney, D. A., \& Burney, L. P. (2007). Paleoecology and “inter-situ” restoration on Kaua'i, Hawai'i. Frontiers in Ecology and the Environment, 5, 483-490.

Caffarri, S., Passarini, F., Bassi, R., \& Croce, R. (2007). A specific binding site for neoxanthin in the monomeric antenna proteins CP26 and CP29 of Photosystem II. FEBS Letters, 581(24), 4704-4710.

Cope, K. R., \& Bugbee, B. (2013). Spectral effects of three types of white lightemitting diodes on plant growth and development: Absolute versus relative amounts of blue light. HortScience, 48(4), 504-509.

Cruz-Cruz, C. A., González-Arnao, M. T., \& Engelmann, F. (2013). Biotechnology and conservation of plant biodiversity. Resources, 2, 73-95.

Dingenen, J. V., De Milde, L., Vermeersch, M., Maleux, K., De Rycke, R., De Bruyne, M., Storme, V., Gonzalez, N., Dhondt, S., \& Inze, D. (2016). Chloroplasts are central players in sugar-induced leaf growth. Plant Physiology, 171(1), 590-605.

Dong, C., Fu, Y., Liu, G., \& Liu, H. (2014). Low light intensity effects on the growth, photosynthetic characteristics, antioxidant capacity, yield and quality of wheat (Triticum aestivum L.) at different growth stages in BLSS. Advances in Space Research, 53, 1557-1566.

Dou, H., Niu, G., Gu, M., \& Masabni, J. G. (2017). Effects of light quality on growth and phytonutrient accumulation of herbs under controlled environments. Horticulturae, 3(2), 36.

Drobyk, N. M., Grytsak, L. R., Mel'nyk, V. M., Kravets, N. B., Konvalyuk, I. I., Twardovska, M. O., \& Kunakh, V. A. (2015). In vitro manipulation and propagation of Gentiana L. species from the Ukrainian Flora. In: The Gentianaceae - Volume 2: Biotechnology and Applications. Springer, Berlin, Heidelberg, 45-79.

Folta, K. M., \& Childers, K. S. (2008). Light as a growth regulator: Controlling plant biology with narrow-bandwidth solid-state lighting systems. HortScience, 43(7), 1957-1964.

Folta, K. M., \& Maruhnich, S. A. (2007). Green light: A signal to slow down or stop. Journal of Experimental Botany, 58(12), 3099-3111.

Franklin, K. A., Larner, V. S., \& Whitelam, G. C. (2005). The signal transducing photoreceptors of plants. The International Journal of Developmental Biology, 49, 653-664.

Golovatskaya, I. F. (2005). The role of cryptochrome 1 and phytochromes in the control of plant photomorphogenetic responses to green light. Russian Journal of Plant Physiology, 52(6), 822-829.

Gong, J., Zhang, Z., Zhang, C., Zhang, J., \& Ran, A. (2018). Ecophysiological responses of three tree species to a high-altitude environment in the southeastern tibetan plateau. Forests, 9(2), 48.

Govorov, P. P., Velyt, I. A., Shchyrenko, V. V., \& Pylypchuk, R. V. (2011). Dzherela svitla dlja vyroshhuvannja ovochiv v umovah zakrytogo g'runtu [Lamp surfaces for vegetables in conditions of suspended soil]. Dzhura, Ternopil' (in Ukranian).

Gururani, M. A., Venkatesh, J., \& Tran, L. S. (2015). Regulation of photosynthesis during abiotic stress-induced photoinhibition. Molecular Plant, 8(9), 1304-1320.

Havaux, M., Bonfils, J. P., Lütz, C., \& Niyogi, K. K. (2000). Photodamage of the photosynthetic apparatus and its dependence on the leaf developmental stage in the npq1 Arabidopsis mutants deficient in the xanthophyll cycle enzyme violaxanthin de-epoxidase. Plant Physiology, 124(1), 273-284.

Hogewoning, S. W., Wientjes, E., Douwstra, P., Trouwborst, G., van Ieperen, W., Croce, R., \& Harbinson, J. (2012). Photosynthetic quantum yield dynamics: From photosystems to leaves. The Plant Cell, 24(5), 1921-1935. 
Hrytsak, L. R., Melnyk, V. M., Konvaliuk, I. I., Kravets, N. B., Mosula, M. Z., \& Drobyk, N. M. (2017). Mikroklonal'ne rozmnozhennja vydiv rodu Gentiana L. flory Ukrai'ny [Microclonal propagation of Gentiana L. species from the Ukrainian flora]. Scientific Issues Ternopil Volodymyr Hnatiuk National Pedagogical University. Series Biology, 1(68), 74-82 (in Ukranian).

Kabashnikova, L. F. (2011). Fotosinteticheskij apparat i potencial hlebnyh zlakov [Photosynthetic apparatus and the potential of cereals]. Belorusskaja nauka, Minsk (in Russian).

Kaiserli, E., \& Chory, J. (2016). The role of phytochromes in triggering plant developmental transitions. In: eLS. John Wiley \& Sons Ltd, Chichester.

Karnachuk, R. A., Negretskii, V. A., \& Golovatskaya, I. F. (1990). Gormonal'nyj balans lista rastenij na svetu raznogo spektral'nogo sostava [Hormonal balance in the plant leaf under light differing in quality]. Russian Journal of Plant Physiology, 37(3), 527-534 (in Russian).

Keziah, S. M., \& Devi, C. S. (2017). Essentials of conservation biotechnology: A mini review. IOP Conference Series: Materials Science and Engineering, 263, 022047.

Kiran, G., Venugopal, R. B., Jabeen, F. T. Z., Kaviraj, C. P., \& Srinath, R. (2004) Rapid regeneration of Mentha piperita L. from shoot tip and nodal explants. Indian Jounal of Biotecnology, 3, 594-598.

Kobiv, Y., Prokopiv, A., Nachychko, V., Borsukevych, L., \& Helesh, M. (2017) Distribution and population status of rare plant species in the Marmarosh Mountains (Ukrainian Carpathians). Ukrainian Botanical Journal, 74(2), 163-176.

Kodun-Ivanova, M. A. (2017). Pokazateli vodnogo stressa mikroklonal'no razmnozhennyh rastenij osiny Populus tremula pri ih vyrashhivanii v uslovijah ex vitro [Indicators of water-stress of microclonal aspen Populus tremula to the ex vitro conditions]. Trudy Belarusian State Technological University, 1(2), 146-155.

Kramer, F. T., \& Havens, K. (2009). Plant conservation genetics in changing world. Trends in Plant Science, 14(11), 599-607.

Kucherjavyi, V. P., Mokryj, V. I., Shymkiv, O. B., Bashuc'ka, U. B., Bejnc, S., \& Viljem, B. (2003). Diagnostyka ta optymizacija bio-naturoju stijkosti fitomeliorantiv devastovanyh landshaftiv [Diagnostic and optimisation by bio-natura of vitality of phytomeliorant of devastated landscape]. Scientific bulletin of UNFU, 13(5), 303-307 (in Ukranian).

Kuster, V. C., De Castro, S. A. B., \& Vale, F. H. A. (2016). Photosynthetic and anatomical responses of three plant species at two altitudinal levels in the Neotropical savannah. Australian Journal of Botany, 64(8), 696-703.

Lau, O. S., \& Deng, X. W. (2010). Plant hormone signaling lightens up: Integrators of light and hormones. Current Opinion in Plant Biology, 13(5), 571-577.

Leong, T. Y., \& Anderson, J. M. (1984). Adaptation of the thylakoid membranes of pea chloroplast to light intensities. I. Study on the distribution of chlorophyll-protein complexes. Photosynthesis Research, 5(2), 105-115.

Lichtenthaler, H. K., Marek, A. A., Kalina, M. V., \& Urban, O. J. (2007). Differences in pigment composition, photosynthetic rates and chlorophyll fluorescence images of sun and shade leaves of four tree species. Plant Physiology and Biochemistry, 45(8), 577-588.

Ling, Q., \& Jarvis, P. (2015). Functions of plastid protein import and the ubiquitin-proteasome system in plastid development. Biochimica et Biophysica Acta (BBA) - Bioenergetics, 1847(9), 939-948.

Margitay, L. (2006). Osoblyvosti vmistu fotosyntezujuchyh pigmentiv u roslyn introdukovanyh vydiv rodiv Sedum L. i Crassula L. [Features of the content of photosynthetic pigments in plants of introduced species of genera Sedum L. and Crassula L.]. Bulletin Taras Shevchenko National University of Kyiv. Series Introduction and Conservation of Plant Diversity, 10, 38- 40 (in Ukranian).

Maschinski, J., \& Albrecht, M. A. (2017). Center for plant conservation's best practice guidelines for the reintroduction of rare plants. Plant Diversity, 39(6), 390-395.

Matsuda, R., Ohashi-Kaneko, K., Fujiwara, K., \& Kurata, K. (2007). Analysis of the relationship between blue-light photon flux density and the photosynthetic properties of spinach (Spinacia oleracea L.) leaves with regard to the acclimation of photosynthesis to growth irradiance. Soil Science and Plant Nutrition, 53(4), 459-465.

Mayorova, O. Y., Hrytsak, L. R., \& Drobyk, N. M. (2015a). The strategy of Gentiana lutea L. populations in the Ukrainian Carpathians. Russian Journal of Ecology, 46(1), 43-50.

Mayorova, O. Y., Hrytsak, L. R., \& Drobyk, N. M. (2015b). Adaptation of Gentiana lutea L. plants obtained in vitro to ex vitro and in situ condition. Biotechnologia Acta, 8(6), 77-86.

Mezhuts, B. K. (2009). Primenenie dimetilsul'foksida v kachestve rastvoritelja fotosinteticheskih pigmentov v polevyh issledovanijah [Application of dimethylsulfoxide as a solvent of photosynthetic pigments in field investigations]. Bulletin of State Agrarian University of Armenia, 3, 40-44 (in Russian).
Murashige, T., \& Skoog, F. A. (1962). A revised medium for rapid growth and bioassays with tobacco tissue culture. Physiologia Plantarum, 15(3), 473-497.

Nemoykina, A. L., \& Karnachuk, R. A. (2002). Sovmestnoe dejstvie sveta raznogo spektral'nogo sostava i jekzogennyh gormonov na mezostrukturu Yucca elephantipes R. v kul'ture in vitro [The combined action of light of different spectral composition and exogenous hormones on the Yucca elephantipes R. mesostructure in vitro culture]. Journal Investigated in Russia, 174, 1930-1937 (in Russian).

Oceania, C., Doni, T., Tikendra, L., \& Nongdam, P. (2015). Establishment of efficient in vitro culture and plantlet generation of tomato (Lycopersicon esculentum Mill.) and development of synthetic seeds. Journal of Plant Sciences, 10(1), 15-24.

Ouzounis, T., Rosenqvist, E., \& Ottosen, C.-O. (2015). Spectral effects of artificial light on plant physiology and secondary metabolism: A review. HortScience, 50(8), 1128-1135.

Rossi, M., Fisogni, A., \& Galloni, M. (2016). Biosystematic studies on the mountain plant Gentiana lutea L. reveal variability in reproductive traits among subspecies. Plant Ecology and Diversity, 9(1), 97-104.

Rybchenko, L. S., \& Savchuk, S. V. (2015). Potencial gelioenergetychnyh klimatychnyh resursiv sonjachnoi' radiacii' v Ukrai'ni [Potential of the climatic solar radiation energy resources in Ukraine]. Ukrainian Geographical Journal, 4, 16-23 (in Ukrainian).

Sáez, P. L., Bravo, L. A., Sáez, K. L., Sánchez-Olate, M., Latsague, M. I., \& Ríos, D. G. (2012). Photosynthetic and leaf anatomical characteristics of Castanea sativa: A comparison between in vitro and nursery plants. Biologia Plantarum, 56(1), 15-24.

Sarasan, V., Cripps, R., Ramsay, M. M., Atherton, C., McMichen, M., Prendergast, G., \& Rowntree, J. K. (2006). Conservation in vitro of threatened plants-progress in the past decade. In Vitro Cellular and Developmental Biology - Plant, 42(3), 206-214.

Schöttler, M. A., \& Tóth, S. Z. (2014). Photosynthetic complex stoichiometry dynamics in higher plants: Environmental acclimation and photosynthetic flux control. Frontiers in Plant Science, 5, 188.

Strashniuk, N. M., Hrytsak, L. R., Leskova, O. M., \& Melnyk, V. M. (2004) Vvedennja v kul'turu in vitro dejakyh vydiv rodu Gentiana L. [Introduction to the in vitro culture of some species of genus Gentiana L.]. Physiology and biochemistry of cultivated plants, 36(4), 327-334 (in Ukranian).

Sun, Y., \& Zerges, W. (2015). Translational regulation in chloroplasts for development and homeostasis. Biochimica et Biophysica Acta, 1847(9), 809-820.

Syvash, O. O., Fomishyna, R. N., Zaharova, T. O., \& Zolotar'ova, E. K. (2016). Hhlorofilazna aktyvnist' i pigmentnyj sklad lystkiv roslyn riznyh jarusiv shyrokolystjanogo lisu [Chlorophyllase activity and pigment composition in leaves of forest plants of different layers of broad-leaved forest]. The Bulletin of Kharkiv National Agrarian University. Series Biology, 2(38), 75-83 (in Ukrainian).

Tanada, T. (1984). Interaction of green or red light with blue light on the dark closure Albizzia pinnules. Physiologia Plantarum, 61(1), 35-37.

Velyt, I. A., \& G'uzyk, D. V. (2013). Vybir dzherel svitla dlja optychnogo oprominennja roslyn tomativ, ogirkiv ta rozsady [Selection of light sources for optical irradiation of plants of tomatoes, cucumbers and seedlings]. Control, Navigation and Communication Systems, 25, 128-132 (in Ukranian).

Viazov, E. V., \& Shalyho, N. V. (2016). Aktivnost' fotosinteticheskogo apparata i zashhitnaja sistema rastenij ogurca (Cucumis sativus L.) pri uzkopolosnom osveshhenii razlichnogo spektral'nogo sostava [Photosynthetic apparatus and defense system of cucumber (Cucumis sativus L.) plants under led lighting of different spectral composition]. Proceedings of the National Academy of Sciences of Belarus. Series of Biological Sciences, 4, 19-26 (in Russian).

Vicente, C., \& Garcia, I. (1981). Decrease in phytochrome pelletability induced by green + far-red light in Trifolium repens. Biochemical and Biophysical Research Communication, 100(1), 17-22.

Volis, S., \& Blecher, M. (2010). Quasi in situ: A bridge between ex situ and in situ conservation of plants. Biodiversity and Conservation, 19(9), 2441-2454.

Voskresenskaya, N. P. (1987). Fotoreguljatornye reakcii i aktivnost' fotosinteticheskogo apparata [Photoregulatory reactions and activity of the photosynthetic apparatus]. Russian Journal of Plant Physiology, 34(4), 669-684 (in Russian).

Walters, R. G. (2005). Towards an understanding of photosynthetic acclimation. Journal of Experimental Botany, 56(411), 435-447.

Wang, H., \& Deng, X. W. (2002). Phytochrome signaling mechanism. In: The Arabidopsis book, 3. The American Society of Plant Biologists, Rockville.

Zavoruev, V. V., \& Zavorueva, E. N. (2011). Fluorescencija list'ev topolej, rastushhih vblizi avtomobil'nyh dorog [Fluorescence of poplar leaves growing near highways]. Atmospheric and Oceanic Optics, 24(5), 437-440 (in Russian). 